С. В. ЧЕРНЮК, А. С. КОЗЛЮК, Р. М. КИРИЧЕНКО (Київ)

\title{
ІНСТРУМЕНТАЛЬНА ДІАГНОСТИКА МІОКАРДИТУ: СУЧАСНІ МОЖЛИВОСТІ
}

ДУ «Національний науковий центр «Інститут кардіології ім. М. Д. Стражеска» НАМН України <vertebrata@bigmir.net>

\begin{abstract}
Нами досліджено діагностичну цінність магнітно-резонансної томографії (МPT) серия та спекл-трекінг ехокардіографії у хворих з клінічно підозрюваним міокардитом. Обстежено 62 пачієнти з клінічно підозрюваним дифузним міокардитом на 1-му місяці від дебюту захворювання та через 12 міс спостереження. В результаті проведених досліджень встановлено, що на 1-й місяць від дебюту дифузного міокардиту спостерігається значна дилатація лівого шлуночка (ЛШ) та зниження його скоротливої здатності, що обумовлено активним запальним процесом, а через 12 міс спостереження на фоні регресу набряку і гіпереміі та розвитку фібротичних змін міокарда відбувається поступове відновлення скоротливої функиї серцевого м'яза. У хворих на дифузний міокардит запальні зміни міокарда, виявлені при МРТ серия, асоціюються з порушенням глобальної скоротливості ЛШІ як в дебюті захворювання, так і через 12 міс спостереження.
\end{abstract}

Ключові слова: міокардит, динамічне спостереження, глобальна деформація міокарда, набряк, гіперемія, фіброз.

Вступ. Актуальність проблеми міокардиту обумовлена насамперед тим, що захворювання частіше спостерігається в осіб молодого працездатного віку і при тяжкому перебігу може призводити до стійкої втрати працездатності, інвалідизації і смерті $[5,9,22]$. Клінічний перебіг міокардиту характеризується значною гетерогенністю, непередбачуваним перебігом, що в багатьох випадках обумовлює необхідність застосування комплексу високовартісних методів діагностики [3, 21, 22]. Нині міокардит залишається однією з небагатьох нозологіних одиниць, для якої не ухвалено рекомендацій з діагностики і лікування Європейського товариства кардіологів, а існують лише положення Робочої групи із захворювань міокарда та перикарда, які, на думку багатьох дослідників, не охоплюють проблеми всебічно [5].

Останніми роками в зарубіжній літературі з'явилася велика кількість публікацій про діагностичну цінність спекл-трекінг (СТ) ехокардіографії (ехоКГ) з вимірюванням показників глобальної деформації міокарда та їх швидкостей для дослідження функціонального стану серця у пацієнтів з міокардитом $[1,2,6,7$, 10]. Чутливість методу для виявлення міокардиту, за різними даними, досягає 90 \%, специфічність - 71 \%, при цьому найбільш інформативним є зниження показників, що характеризують повздовжню деформацію міокарда та її швидкість $[12,15,19]$.

Широкомасштабними зарубіжними дослідженнями доведено високу інформативність магнітно-резонансної томографії (МРТ) для діагностики міокардиту. Особливу цінність це дослідження має в Україні через обмежене використання ендоміокардіальної біопсії. За даними різних авторів, чутливість і специфічність МРТ для виявлення запальних, фібротичних або некротичних змін серцевого м'яза, характерних для міокардиту, досягають 90 \% [9, 14, 16, 17, 23]. Актуальність МРТ серця для діагностики міокардиту підтверджується затвердженими критеріями діагностики, так званими Lake Louise Criteria [8, 11]. Беззаперечна інформативність МРТ в складних випадках, при диференціальній діагностиці міокардиту з інфарктом міокарда в гострому періоді, дилатаційною кардіоміопатією, кардіальним амілоїдозом, кардіоміопатією такоцубо тощо [18, 20, 23]. Останніми роками багатьма зарубіжними дослідниками встановлено, що характерні для міокардиту МРТ-зміни у поєднанні з порушеннями глобальної деформації, виявле- 
ними при проведенні СТ ехоКГ, практично із 100 \% вірогідністю свідчать на користь міокардиту [7, 16].

Мета дослідження - встановити діагностичну цінність магнітно-резонансної томографії серця та спекл-трекінг ехокардіографії у хворих з клінічно підозрюваним міокардитом.

Матеріали і методи. Для досягнення поставленої мети обстежено 62 пацієнти 3 клінічно підозрюваним гострим дифузним міокардитом (ДМ); 42 (67,7 \%) чоловіки і 20 (32,3 \%) жінок, середній вік - (32,3 $\pm 2,7)$ року, хворі знаходились на обстеженні та стаціонарному лікуванні у відділі некоронарних хвороб серця та ревматології ДУ ННЦ «Інститут кардіології ім. М. Д. Стражеска» НАМН України 32015 по 2017 р. Діагноз клінічно підозрюваного міокардиту встановлювали на основі положень Робочої групи із захворювань міокарда та перикарда Свропейського товариства кардіологів (2013р.) і відповідного проекту рекомендацій з діагностики та лікування міокардиту Асоціації кардіологів України [3, 5]. Ішемічну хворобу серця було виключено за допомогою коронаровентрикулографії або комп'ютерної томографії коронарних судин. У всіх пацієнтів був синусовий ритм і знижена фракція викиду (ФВ) лівого шлуночка (ЛШ), що становило $\leq 40 \%$ згідно із стандартами з діагностики і лікування серцево-судинних захворювань, та функціональний клас (ФК) серцевої недостатності (CH) за критеріями НьюЙоркської асоціації серця (NYHA) II або вище [4]. Обстеження проводили двічі: на 1-й місяць від дебюту міокардиту та через 12 міс спостереження.

Всі хворі отримували стандартну терапію серцевої недостатності згідно 3 останніми рекомендаціями з діагностики і лікування Європейського товариства кардіологів та відповідними стандартами з діагностики та лікування Асоціації кардіологів України, що включала бета-блокатори, інгібітори ангіотензинперетворюючого ферменту, антагоністи мінералокортикоїдних рецепторів, діуретики [4]. Антиаритмічну терапію та антикоагулянти призначали за показаннями.

За допомогою спекл-трекінг (СТ) ехоКГ на ультразвуковому діагностичному апараті Aplio Artida SSH - 880 CV, Toshiba Medical System Corporation (Японія) вимірювали величини поздовжньої глобальної систолічної деформації (ПГСД), циркулярної глобальної систолічної деформації (ЦГСД), радіальної глобальної систолічної деформації (РГСД) та їх швидкості - відповідно ШПГСД, ШЦГСД та ШРГСД. У 2D-режимі в період систоли та діастоли обчислювали кінцеводіастолічний (КДО) і кінцево-систолічний (КСО) об’єми ЛШ за формулою «площа-довжина» в апікальному чотирикамерному доступі, ФВ ЛШ розраховували за методом Симпсона.

MPT серця проводили на апараті Toshiba Vantage Titan HSR 1,5 Тесла (Японія). Оцінювали зображення серця по короткій і довгій осі в трьох режимах: Т1-зваженому через 1-2 хв після введення контрастної речовини, Т2-зваженому і режимі відстроченого контрастування через 10-15 хв після введення контрасту. Як контрастну речовину використовували томовіст.

Статистичну обробку отриманих даних проводили з використанням програм Microsoft Excel i Statistica 6.0 на основі порівняльної статистики із застосуванням $t$-критерію Стьюдента. Для визначення асоціативних зв’язків між перемінними використовували кореляційний аналіз.

Результати та їх обговорення. В результаті аналізу СТ ехоКГ-показників було встановлено, що через 12 міс у хворих на міокардит поліпшилась глобальна скоротливість серцевого м'яза, про що свідчило достовірне збільшення показників ПГСД, ЦГСД та ШПГСД (табл. 1). Слід відзначити, що порівняно з дебютом захворювання через 12 міс спостереження відмічалось достовірне збільшення ФВ ЛШ - $(31,7 \pm 2,6) \%$ i $(43,5 \pm 3,2) \%($ P < 0,01) та КДО ЛШ - $(218,4 \pm 17,3)$ мл і $(168,2 \pm 12,9)$ мл $(\mathrm{P}<0,05)$ відповідно. Таким чином, обидві методики оцінки скротливої здатності ЛШ підтверджують часткове відновлення скоротливості міокарда через 12 міс спостереження.

За даними МРТ, на 1-й місяць від дебюту дифузного міокардиту відмічали ознаки активного запального процесу в міокарді, про що свідчили набряк і гіпе- 
ремія серцевого м'яза відповідно в 83,8 і 77,4 \% випадків (табл. 2). Через 12 міс спостереження виявлено здебільшого фібротичні зміни, що вказувало на зменшення активності запального процесу або його усунення. Однак набряк і гіперемію виявляли в 40,3 і 29 \% випадків, що, очевидно, можна пояснити переходом запального процесу в хронічну стадію.

Таблиця 1. Показники глобальної деформації та її швидкості у хворих на міокардит $(M \pm m)$

\begin{tabular}{l|c|c}
\hline \multirow{2}{*}{ Показник } & \multicolumn{2}{|c}{ Величина показника $(M \pm m)$ в групах } \\
\cline { 2 - 3 } & 1-й місяць & Через 12 міс \\
\hline \hline ПГСД, \% & $7,41 \pm 0,66$ & $12,39 \pm 1,08^{* *}$ \\
ЦГСД, \% & $7,26 \pm 0,54$ & $10,74 \pm 0,98^{*}$ \\
РГСД, \% & $12,59 \pm 1,17$ & $13,80 \pm 1,53$ \\
ШПГСД, $\mathrm{c}^{-1}$ & $0,55 \pm 0,06$ & $0,79 \pm 0,06^{* *}$ \\
ШЦГСД, $\mathrm{c}^{-1}$ & $0,57 \pm 0,07$ & $0,72 \pm 0,08$ \\
ШРГСД, $\mathrm{c}^{-1}$ & $1,22 \pm 0,13$ & $1,31 \pm 0,11$ \\
\hline
\end{tabular}

Прим ітка. Різниця показників достовірна порівняно з такими на 1 -й місяць: $* \mathrm{P}<0,05$; ** $\mathrm{P}<0,01$.

Таблиия 2. МРТ-зміни серцевого м'яза у хворих на міокардит в динаміці 12-місячного спостереження, \%

\begin{tabular}{l|c|c}
\hline \multicolumn{1}{c|}{ Патологічні зміни } & 1-й місяць & Через 12 міс \\
\hline \hline Набряк & 83,8 & 40,3 \\
Гіперемія & 77,4 & 29 \\
Фіброз/некроз & 41,9 & 87,1 \\
\hline
\end{tabular}

Слід відзначити, що певної специфічної локалізації запального ураження міокарда, за результатми МРТ серця, не виявлено: запальні і фібротичні зміни приблизно з однаковою частотою відмічали в міжшлуночковій перетинці, задній і боковій стінках ЛШ, ураження правого шлуночка спостерігали в 27,4% випадків. Втягнення перикарда в патологічний процес на 1-й місяць від дебютиу захворювання спостерігали в 33,9 \% випадків, воно включало в більшості випадків невелику або помірну кількість перикардіального випоту, як правило, в ділянці бокової і/або задньої стінки ЛШ. Слід зауважити, що патологічні зміни перикарда виявляли здебільшого в зонах запального ураження міокарда, що свідчило про периміокардит - поняття, нещодавно введене в клінічну практику і яке ввійшло до сучасної класифікації міокардиту [4, 13].

За допогою кореляційного аналізу нами було встановлено кореляційний зв'язок між зниженням ПГСД та ШПГСД і запальними змінами міокарда (набряк і гіперемія) за результатами МРТ як на 1-й місяць від дебюту захворювання $(r=-0,73 ; \mathrm{P}<0,01)$ та $(r=-0,55 ; \mathrm{P}<0,02)$ відповідно, так і через 12 міс спостереження - $(r=-0,63 ; \mathrm{P}<0,05)$ та $(r=-0,47 ; \mathrm{P}<0,05)$ відповідно. Отримані дані свідчать про асоціацію порушень скоротливої функції ЛШ із запальним процесом в міокарді.

Таким чином, СТ ехоКГ та МРТ серця є інформативними методами діагностики міокардиту, що можна використовувати для довготривалого спостереження за хворими з метою моніторингу скоротливої здатності серця та еволюції запального процесу в міокарді. Безумовно, одним з основних завдань на сучасному етапі $€$ широкомасштабне введення цих сучасних неінвазивних методик в діагностичний алгоритм при встановленні діагнозу міокардиту, а також освоєння спеціалістами з МРТ діагностики найсучасніших програм з Т1 та Т2 картування.

Висновки. 1. На 1-й місяць від дебюту дифузного міокардиту спостерігається значна дилатація ЛШ та зниження його скоротливої здатності, що обумовлено активним запальним процесом. Через 12 міс спостереження на фоні регресу на- 
бряку і гіперемії та розвитку фібротичних змін міокарда відбувається поступове відновлення скоротливої функції серцевого м’яза. 2. У хворих на дифузний міокардит запальні зміни міокарда, виявлені при МРТ серця, асоціюються з порушенням глобальної скоротливості ЛШ як в дебюті захворювання, так і через 12 міс спостереження.

\section{С пи сок лі т ер а т у ри}

1. Коваленко В. Н., Несукай Е. Г., Чернюк С. В., Даниленко А. А. Значение спекл-трекинг эхокардиографии в дифференциальной диагностике хронического диффузного миокардита и дилатационной кардиомиопатии // Укр. кардіол. журн. - 2013. № 1. - С. 64-69.

2. Коваленко В. Н., Несукай Е. Г., Чернюк С. В. Роль современных неинвазивных методик визуализации сердца в диагностике миокардита / / Там же. - 2013. - № 3. - С. 101-108.

3. Коваленко В. М., Несукай О. Г., Воронков Л. Г. та ін. Діагностика та лікування міокардиту: рекомендації робочої групи з хвороб міокарда, перикарда, ендокарда та клапанів серця Асоціації кардіологів України (проект) // Там само. - 2014. № 3. - C. 15-21.

4. Коваленко В. М., Несукай О. Г., Чернюк С. В. Класифікація міокардиту, перикардиту, інфекційного ендокардиту // Серцевосудинні захворювання: класифікація, стандарти діагностики та лікування / За ред. В. М. Коваленка, М. І. Лутая, Ю. М. Сіренка, О. С. Сичова. - К.: Моріон, 2016. - 192 с.
1. Kovalenko V.N., NesukajE. G., ChernyukS.V., Danilenko A. A. Znachenie spekl-treking ehkhokardiografii v differencial'noj diagnostike hronicheskogo diffuznogo miokardita i dilatacionnoj kardiomiopatii // Ukr. kardiol. zhurn. - 2013. - № 1. - S. 64-69.

2. Kovalenko V.N., Nesukaj E. G., ChernyukS.V. Rol' sovremennyh neinvazivnyh metodik vizualizacii serdca v diagnostike miokardita // Tam zhe. - 2013. - № 3. - S. 101-108.

3. Kovalenko V.M., NesukajO. G., Voronkov L. G. ta in. Diagnostika ta likuvannya miokarditu: rekomendaciï robochoï grupi z hvorob miokarda, perikarda, endokarda ta klapaniv sercya Asociaciï kardiologiv Ukraïni (proekt) // Tam samo. - 2014. - № 3. - S. 15-21.

4. Kovalenko V.M., NesukajO. G., ChernyukS.V. Klasifikaciya miokarditu, perikarditu, infekcijnogo endokarditu // Sercevo-sudinni zahvoryuvannya: klasifikaciya, standarti diagnostiki ta likuvannya / Za red. V. M. Kovalenka, M. I. Lutaya, YU. M. Sirenka, O. S. Sichova. - K.: Morion, 2016. - 192 s.

5. Caforio A. L. P., Pankuweit S., Arbustini E. et al. Current state of knowledge on aetiology, diagnosis, management and therapy of myocarditis: a position statement of the ESC Working group on myocardial and pericardial diseases // Eur. Heart J. - 2013. - Vol. 34. - P. 2422-2436.

6. Di Beela G., Coglitore S., Zimbulatti $C$. et al. Strain Doppler echocardiography can identify longitudinal myocardial dysfunction derived from edema in acute myocarditis // Int. J. Cardiol. - 2008. - Vol. 126, N 2. - P. 279-280.

7. Di Beela G., Caeta M., Pingitore A. et al. Myocardial deformation in acute myocarditis with normal left ventricular wall motion - a cardiac magnetic resonance and 2-dimensional strain echocardiography study // Circ. J. - 2010. - Vol. 74, N 6. - P. $1205-1213$.

8. Friedrich M. G., Sechtem U., Schulz-MengerJ. et al. Cardiovascular magnetic resonance in myocarditis: a Journal of the American College of Cardiology White Paper // J. Am. Coll. Cardiol. - 2009. - Vol. 53, N 17. - P. 1475-1487.

9. Goitein O., Matetzky S., Beinart R. et al. Acute myocarditis: noninvasive evaluation with cardiac MRI and transthoracic echocardiography // Am. J. Rentgenology. - 2009. - Vol. 192. - P. 254 258.

10. Hsiao J. F., Koshino Y., Bonninchsen C. R. et al. Speckle tracking echocardiography in acute myocarditis // Int. J. Cardiovasc. Imag. - 2013. - Vol. 29. - P. $275-284$.

11. Hundley W. G., Bluemke D. A., Finn J. P. et al. ACCF/ACR/AHA/ NASCI/SCMR 2010 Expert consensus document on cardiovascular magnetic resonance: a report of the American college of cardiology foundation task force on the expert consensus documents // Circulation. - 2010. Vol. 121. - P. 2462-2508.

12. Hyafil F., Serfaty J.M., Ducrocq G. et al. Speckle tracking echocardiography can identify the location of myocardial injury in acute myocarditis // Circulation. - 2008. - Vol. 118, N 5. P. 851.

13. Imazio M., Cooper L. T. Management of myopericarditis // Expert Rev. Cardiovasc. Ther. 2013. - Vol. 11. - P. 193-201.

14. Jeserich M., Konstantinides S., PavlikJ., Bode C., Geibel A. Non-invasive imaging in the diagnosis of acute viral myocarditis / / Clin. Res. Cardiol. - 2009. - Vol. 98. - P. 753-763. 
15. Khoo N. S., Myers K., Smallhorn J., Paterson I. Abnormal left ventricular circumferential strain, strain rate and rotation parameters using speckle tracking imaging in acute myocarditis as evidenced on cardiac magnetic resonance imaging // Circulation. - 2009. - Vol. 120 (Abstract 525). - P. 351.

16. Kadkhodayan A., Chareonthaitawee P., Raman S. V., Cooper L. T. Imaging of inflammation in unexplained cardiomyopathy // JACC Cardiovasc. Imaging. - 2016. - Vol. 9, N 5. - P. 603-617.

17. Lurz P., Luecke C., Eitel I. et al. Comprehensive cardiac magnetic resonance imaging in patients with suspected myocarditis: the myoRacer-Trial // J. Am. Coll. Cardiol. - 2016. - Vol. 15. P. $1800-1811$.

18. Mewton N., Dernis A., Bresson D. et al. Myocardial biomarkers and delayed enhancend cardiac magnetic resonance relationship in clinically suspected myocarditis and insight on clinical outcome // J. Cardiovasc. Med. (Hagerstown). - 2015. - Vol. 161. - P. 696-703.

19. Mondillo S., Galderisi M., Mele D. et al. Speckle-tracking echocardiography. A new technique for assessing myocardial function // J. Ultrasound Med. - 2011. - Vol. 30. - P. 71-83.

20. Roottgen R., Christiani R., Freyhardt P. et al. Magnetic resonance imaging findings in acute myocarditis and correlation with immunohistological parameters // Eur. Radiol. - 2011. Vol. 21, N 6. - P. 1259-1266.

21. Sachedeva S., Song X., Dham N. et al. Analysis of clinical parameters and cardiac magnetic resonance imaging as predictors of outcome in pediatric myocarditis // Am. J. Cardiol. - 2015. Vol. 115. - P. 499-504.

22. Shauer F., Gotsman I., Keren A. et al. Acute viral myocarditis: current concepts in diagnosis and treatment // Isr. Med. Assoc. - 2013. - Vol. 15. - P. 180-185.

23. Siepen F., Buss S.J., Messroghli A. et al. T1 mapping in dilated cardiomyopathy with cardiac magnetic resonance: quantification of diffuse myocardial fibrosis and comparison with endomyocardial biopsy // Eur. Heart J. - 2015. - Vol. 16. - P. 210-216.

\title{
ИНСТРУМЕНТАЛЬНАЯ ДИАГНОСТИКА МИОКАРДИТА: СОВРЕМЕННЫЕ ВОЗМОЖНОСТИ
}

\author{
С. В. Чернюк, А. С. Козлюк, Р. М. Кириченко (Киев)
}

Мы изучали диагностическую ценность магнитно-резонансной томографии (МРТ) сердца и спекл-трекинг эхокардиографии у пациентов с клинически подозреваемым миокардитом. В результате проведённых исследований установлено, что в 1-й месяц от дебюта диффузного миокардита наблюдается значительная дилатация левого желудочка (ЛЖ) и снижение его сократительной способности, что обусловлено активным воспалительным процессом. Через 12 мес наблюдения на фоне регресса отёка и гиперемии и развития фибротических изменений миокарда происходит постепенное восстановление сократительной функции ЛЖ. Воспалительные изменения, выявленные при МРТ сердца, ассоциируются с нарушением его сократительной способности как в дебюте заболевания, так и через 12 мес наблюдения.

Ключевые слова: миокардит, динамическое наблюдение, глобальная деформация миокарда, отёк, гиперемия, фиброз.

\section{INSTRUMENTAL DIAGNOSTIC TECHNIQUES FOR MYOCARDITIS CURRENT OPPORTUNITIES}

\author{
S. V. Cherniuk, A. S. Kozliuk, R. M. Kirichenko (Kiev, Ukraine)
}

SI «SC «M. D. Strazhesko Institute of cardiology» NAMS of Ukraine

The purpose of the study was to evaluate diagnostic value of cardiac magnetic-resonance imaging (MRI) and speckle-tracking echocardiography in patients with clinically suspected myocarditis. We examined 62 patients with clinically suspected myocarditis during the $1^{\text {st }}$ month after the disease onset and after 12 months of observation. We report that significant dilatation of left ventricle (LV) and impairment of its systolic function due to active inflammation of the myocardium was observed within the $1^{\text {st }}$ month after disease onset, after 12 months we detected the reduction of myocardial edema and hyperemia with development of fibrotic changes that was sequenced by partial recovery of LV contractile function. We suggest the association between the presence of inflammatory changes and impairment of myocardial global strain in patients with myocarditis on the $1^{\text {st }}$ month after disease onset as also after 12 months of observation.

Key words: myocarditis, dynamic observation, global myocardial strain, edema, hyperemia, fibrosis. 